\title{
CORRELATION OF HUMIC SUBSTANCE TRIHALOMETHANE FORMATION POTENTIAL AND ADSORPTION BEHAVIOR TO MOLECULAR WEIGHT DISTRIBUTION IN RAW AND CHEMICALLY TREATED WATERS
}

\author{
Abdullah M. El-Rehaili ${ }^{1}$ and Walter J. Weber $J_{R^{2}}$ \\ 'Assistant Professor of Civil Engineering, King Saud University, P.O. Box 800, Riyadh 11421, Saudi \\ Arabia and 2 Professor of Environmental Engineering and Chairman, University Program in Water \\ Resources, The University of Michigan, Ann Arbor, MI 48109, U.S.A.
}

(Received January 1986)

\begin{abstract}
The molecular weight distributions (MWDs) of several commercially prepared humic and fulvic acids and organic matter present in natural waters were analyzed by gel chromatography. The responses of these substances to treatment by alum coagulation, lime softening, and activated carbon adsorption were also analyzed, as were their trihalomethane formation potentials before and after each treatment. The treatability characteristics and trihalomethane formation properties of the different organic substances were then related to their respective MWDs. Differences in the MWDs were found to effect differences in the behavior of lumped parameter measures of organic matter (such as TOC) with respect to the several treatment operations. The treatments in turn were observed to alter the MWDs of the organic substances as well as their phenomenological behavior in subsequent process operations.
\end{abstract}

Key words - humic substances, molecular weight distributions, water treatment, adsorption, coagulation, softening, trihalomethane formation potential

\section{INTRODUCTION}

It is generally recognized that humic substances are complex mixtures of compounds having different molecular weights and sizes, and previous studies by the authors have indicated that they behave accordingly with respect to water treatment operations such as coagulation, softening, and adsorption (Weber $e t$ al., 1983; Weber and Jodellah, 1985; Jodellah and Weber, 1985). The investigations described here were designed to analyze the molecular weight distributions (MWDs) for raw and chemically pre-treated humic substances and to evaluate potential correlations between pretreatment and subsequent susceptibility to trihalomethane formation potential (THMFP) and adsorption by activated carbon. Specifically, the analyses were designed to:

-investigate correlations between adsorption of humic compounds of different type and origin and their respective MWDs;

-provide a basis for explaining differences in the

*Aldrich Chemical Co., Milwaukee, WI \& Fluka, AG, Switzerland.

+Contech E.T.C. Ltd, Ottawa, Canada.

+Whatman, Inc., Clifton, N.J.

\$Model No. 105, Talboys Eng. Corp., Emerson, N.J.

Tillipore Corp., Bedford, Mass.

"Calgon Corp., Pittsburg. Pa. observed adsorption behavior of humic substances before and after different chemical pretreatments and,

-identify the influence of chemical treatments and adsorption on the molecular weight (MW) speciation of humic substances, and examine potential correlations, between MWD and THMFP.

\section{EXPERIMENTAL PROCEDURES}

\section{Preparation of samples}

Humic and fulvict acid solutions were prepared in deionized distilled water (DDW) and buffered with $10^{-3} \mathrm{M}$ $\mathrm{Na} \mathrm{HCO}$. Huron River water (the raw water supply for the City of Ann Arbor, Mich.) was settled for $24 \mathrm{~h}$, then filtered through Whatman 934 AH glass fiber filters.t

\section{Pretreatments}

Alum coagulation (pH 6) and lime softening (pH 10) pretreatments were performed in 10-1. glass reactors according to a procedure detailed in an earlier report (Jodellah and Weber, 1985). Mixing was provided in each reactor by a stainless steel stirrer driven by a variable-speed $T$-line electric motor.\$ Samples withdrawn after chemical pretreatment were filtered through $0.45-\mu \mathrm{m}$ membrane fiters. $\uparrow$

Adsorption experiments were conducted in completely mixed batch reactors (CMBRs) at pH 8, a contact time of $24 \mathrm{~h}$, and with F-400 activated carbon $\|$ of $16 / 20$ (U.S. standard sieve) particle size. Samples were filtered through $0.45-\mu \mathrm{m}$ membrane filters at the end of the adsorption period to remove carbon fines. 


\section{Concentration of samples}

Untreated and pretreated samples were concentrated at $35^{\circ} \mathrm{C}$ in a 1-liter vacuum flash evaporator.* Typically, $3000 \mathrm{ml}$ of sample were concentrated to $50 \mathrm{ml}$. The concentration ratio of $60: 1$ was selected to avoid the precipitation and associated loss of TOC that was observed at higher ratios. The concentrated samples were filtered through Whatman $934 \mathrm{AH}$ glass fiber filters and refrigerated awaiting analysis by gel permeation chromatography.

\section{Molecular weight determination}

The separation of a mixture of molecules of different size in a gel column occurs as a result of differences in the degree to which different species permeate the gel particles. Molecules larger than the gel pores move rapidly through the column with the eluant. Smaller molecules permeate the gel to an extent dependent on both their size and on the distribution of gel particle pore sizes, and therefore follow a longer and more tortuous path as they move down the column. As a result, the largest molecules exit the column first, followed by smaller molecules. Comprehensive discussions of the principles and applications of gel permeation chromatography are readily available in the literature (see, for example, Cazes, 1966a, b; Cazes, 1970a, b).

The MWDs of concentrated samples were determined using Sephadex G-75† gel with an upper exclusion limit of 50,000 and a lower exclusion limit of 1000. A 40-cm Pharmacia C 16/40 chromatography glass column having a 1.6- $\mathrm{cm}$ i.d. was used. The column had a bed volume of $77 \mathrm{ml}$ and a 6-ml sample applicator. Deionized distilled water buffered with $10^{-3} \mathrm{M} \mathrm{Na} \mathrm{HCO}_{3}$ and filtered through a $0.45 \mu \mathrm{m}$ membrane filter was employed as the eluant solution.

Dried gel particles were placed in the eluant solution and allowed to swell for at least $24 \mathrm{~h}$. The swollen particles were poured into the column, and the eluant allowed to flow through the column for at least $3 \mathrm{~h}$, after which the samples were injected.

The G-75 column was calibrated with bovine serum albumin (MW 67,000), ovalbumin (MW 43,000), chymotrypsinogen A (MW 25,000), and ribonuclease A (MW 13,700). Blue dextran 2000 (MW 2,000,000) was used to determine the void volume of the column. The calibration resulted in a straight line on a semi-log plot of molecular weight vs elution volume.

Eluant flow through the column was maintained at $0.5 \mathrm{ml}$ $\min ^{-1}$ with an FMI pumpt. In a typical fractionation run, $1-\mathrm{ml}$ of the concentrated sample was injected at the top of the column into a continuous flow of eluant. Organics in the effluent from the gel column were continuously monitored with an LDC u.v. monitor $(254 \mathrm{~nm})$ and HP integrating recorder. I A schematic diagram of the experimental apparatus is given in Fig. I. In addition, 5-ml samples were collected continuously with a fraction collector and the TOCs of these samples subsquently determined using a low level TOC analyzer.\|

\section{RESULTS AND DISCUSSION}

\section{MWDs of untreated solutions}

Gel permeation chromatograms for the humic compounds tested are illustrated in Figs 2-5. As

\footnotetext{
* Buchler Instruments, Fort Lee, N.J.

+Pharmacia Fine Chemicals, Uppsala, Sweden.

†Fluid Metering, Inc., Oyster Bay, NY.

$\S$ Laboratory Data Control.

THP 3390A, Hewlett Packard, Avondale, Pa.

\|DC-80, Dohrmann, Santa Clara, Calif.
}

noted above, effluent from the gel column was monitored for u.v. absorbance and for TOC. Both analytical measures signaled similar separation trends. The MWDs were determined from the protein calibration curve. The MWs reported here for the humic substances are approximate or "apparent" molecular weights in that molecules comprising the humic compounds are likely to have structural characteristics different from those for the calibration proteins, and are therefore likely to behave somewhat differently in the gel permeation process. Nonetheless, the results are valid for comparison of qualitative differences between humic substances from different sources and for evaluation of the relative effects of different treatments and pretreatments.

Three molecular weight regions were clearly identified for the humic and fulvic acid preparations (Figs 2-4), and their corresponding $M W$ ranges and proportions in the mixture calculated. As illustrated in Table 1, the major organic fraction in these humic preparations has a MW of $3000-40,000$, which corresponds to elution volumes of $32.5-71.5 \mathrm{ml}$. Conversely, TOC in Huron River water (Fig. 5) has a somewhat uniform $\mathrm{MW}$ ranging between 1000 and 6000 , corresponding to elution volumes of $60-85 \mathrm{ml}$. The average $\mathrm{MW}$ for TOC in Huron River water is approx. 3000.

An average of approx. $20 \%$ of TOC was lost during concentration of the humic solutions at a ratio of $60: 1$. Higher concentration ratios are generally favored for gel chromatography, but excessive precipitation at higher concentration ratios was observed for these particular experimental solutions. Approximately $98 \%$ of the TOC was recovered from the gel column for all humic solutions tested. The $2 \%$ loss of organics to the gel is near the lower end of a range of $0-13 \%$ losses reported by other investigators (Gjessing and Lee, 1967; Schnoor et al., 1979).

A summary of molecular weight distributions reported in the literature for humic materials from different sources is given in Table 2 . These values generally agree with the findings of the present study in that the predominant species were observed to have MWs in the range of $1000-50,000$.

\section{MWDs of treated solutions}

An important objective of this investigation was a comparison of the MWDs of organics remaining after different chemical pretreatments and adsorption to those of untreated solutions. A summary of experiments performed on the Aldrich humic acid solution and of the effects of different treatments on the TOC of this solution is given in Table 3. As may be noted in the summary given in Table 3, the treatments included varying degrees of activated carbon adsorption, alum coagulation, and lime softening.

Activated carbon adsorption. Figure 6 illustrates MWDs for the untreated Aldrich humic acid solution and for the organics remaining in this solution after treatment by $\mathrm{F}-400$ granular activated carbon. Two 


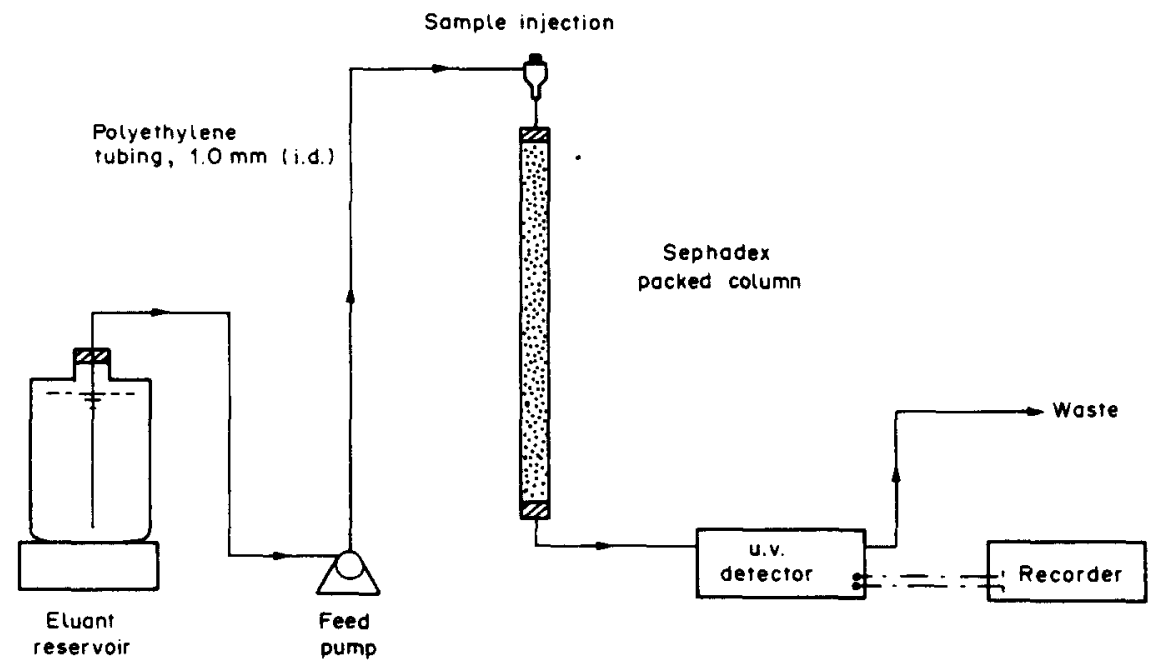

Fig. 1. Schematic diagram of experimental gel permeation system.

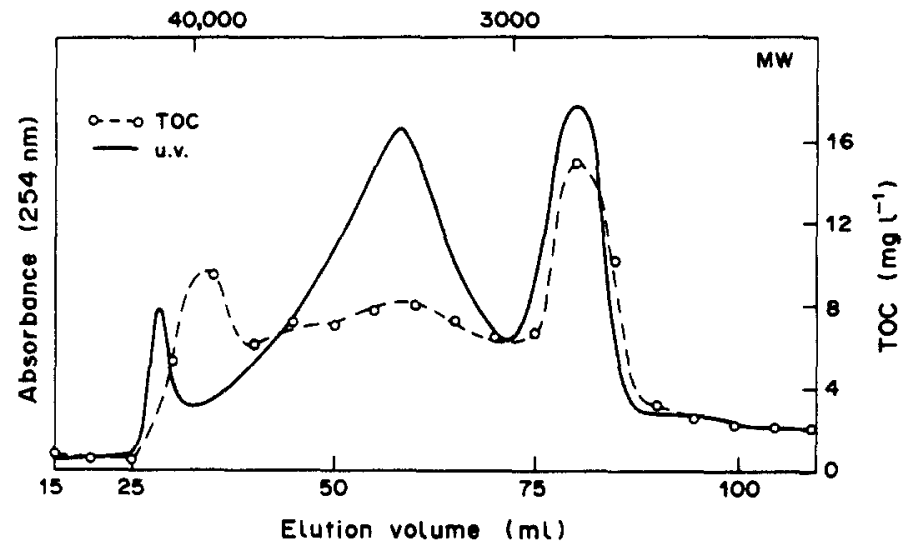

Fig. 2. Gel permeation chromatogram for Aldrich humic acid.

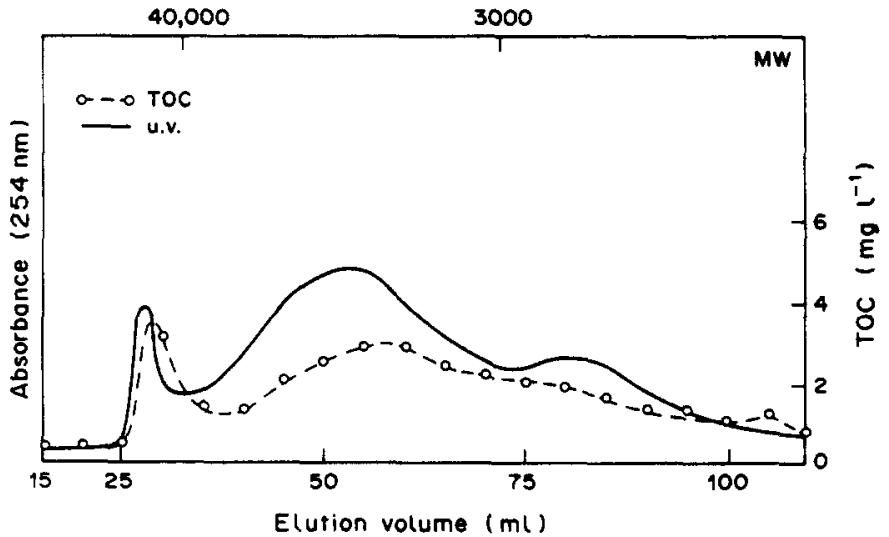

Fig. 3. Gel permeation chromatogram for Fluka humic acid. 


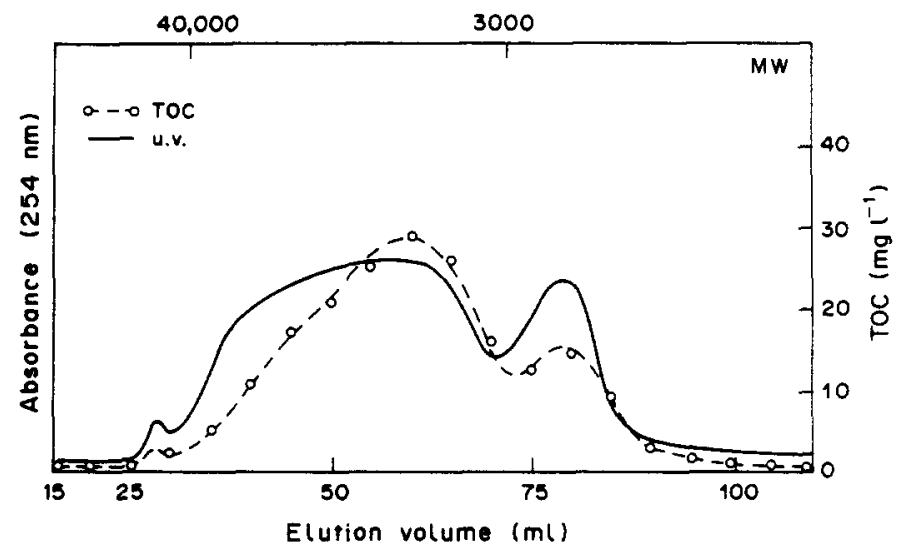

Fig. 4. Gel permeation chromatogram for Contech fulvic acid.

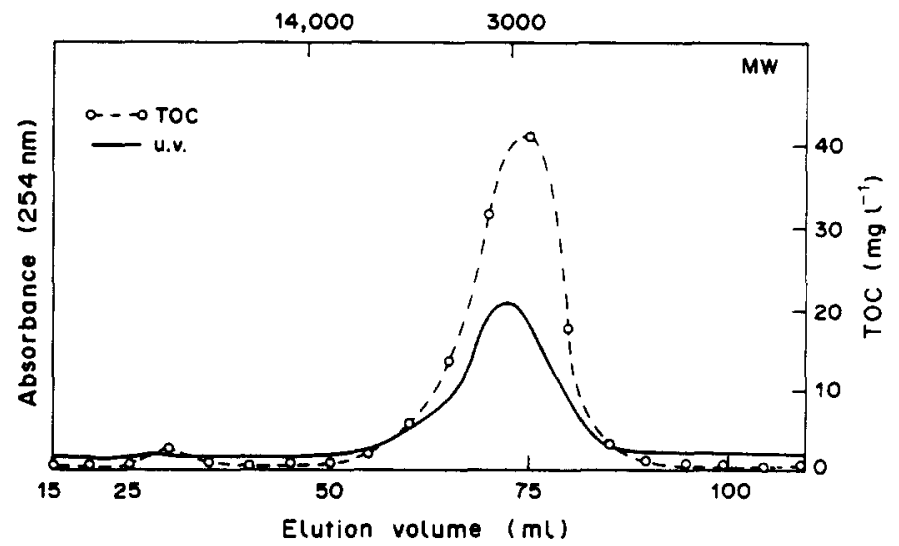

Fig. 5. Gel permeation chromatogram for Huron River water.

levels of TOC reduction were examined; a $42 \%$ TOC reduction $\left(3.0 \mathrm{~g} \mathrm{I}^{-1} \mathrm{GAC}\right)$ and a $73 \%$ TOC reduction $\left(12.0 \mathrm{gl}^{-1} \mathrm{GAC}\right.$ ). Table 4 summarizes the effects of these levels of GAC treatment on each MW fraction in the Aldrich humic acid solution. The data indicate that the degree of adsorption differs among different MW fractions, with fractions in the extremely high MW range $(>40,000)$ being the least adsorbable. At $42 \%$ TOC reduction no adsorption from this highest MW fraction was observed, while reductions of 45 and $64 \%$ of the organics in the intermediate MW $(3000-40,000)$ and low MW $(<3000)$ fractions, respectively, were measured. Similarly, at $73 \%$ TOC reduction only $25 \%$ of the organics in the highest MW range were adsorbed, compared to 85 and $89 \%$ in the intermediate and low MW fractions, respectively.

These findings accord with results reported by other investigators. McCreary and Snoeyink (1980) observed a steady decrease in the extent of adsorption of soil humic and fulvic acid fractions with increasing MW. Lee and Snoeyink (1980) reported similar results, and suggested that the presence of only a small percentage of molecules larger than $50,000 \mathrm{MW}$ in fulvic acid tended to control both the apparent capacity and rate of adsorption of overall organic

Table 1. Initial molecular weight distributions of experimental systems*

\begin{tabular}{cccccc}
\hline $\begin{array}{c}\text { Elution } \\
\text { volume } \\
(\mathrm{ml})\end{array}$ & $\begin{array}{c}\text { Molecular } \\
\text { weight } \\
\text { range }\end{array}$ & $\begin{array}{c}\text { Aldrich } \\
\text { humic acid } \\
(\%)\end{array}$ & $\begin{array}{c}\text { Fluka } \\
\text { humic acid } \\
(\%)\end{array}$ & $\begin{array}{c}\text { Contech } \\
\text { fulvic acid } \\
(\%)\end{array}$ & $\begin{array}{c}\text { Huron River } \\
\text { water } \\
\text { TOC } \\
(\%)\end{array}$ \\
\hline $\begin{array}{c}\% 2.5 \\
32.5-71.5\end{array}$ & $\begin{array}{c}>40,000 \\
>71.5\end{array}$ & 5 & 9 & 3 & - \\
$60.0-85.0$ & $1000-600000$ & 57 & 63 & 72 & - \\
\hline
\end{tabular}

- Molecular weight distributions were determined by calculating areas under the u.v. absorbance chromatogram for corresponding elution volume ranges. 
Table 2. Molecular weight distributions for TOC in organic matter from different sources

\begin{tabular}{cccl}
\hline $\begin{array}{c}\text { Solution } \\
\text { (source) }\end{array}$ & $\begin{array}{c}\text { Molecular } \\
\text { weight } \\
\text { range }\end{array}$ & $\begin{array}{c}\text { TOC } \\
(\%)\end{array}$ & Reference \\
\hline Peat fulvic acid & $>50,000$ & 9 & \\
& $1000-50,000$ & 53 & Lee (1980) \\
& $<1000$ & 39 & \\
Peak Creek, Va & $>42,000$ & 95 & \\
& $7000-42,000$ & 5 & Rest et al. (1983) \\
Iowa River, lowa & $>50,000$ & 0 & \\
& $1000-50,000$ & 86 & Schnoor et al. (1979) \\
& $<1000$ & 14 & \\
\hline
\end{tabular}

matter from unfractionated solutions. It is likely that the very high molecular weight organic fractions are comprised by molecules which are simply too large and bulky to penetrate other than the largest macropores of an activated carbon particle. In this regard, the pore size distribution of activated carbon has been shown to impact its effectiveness for removing humic substances from solution (Weber et al., 1983; Lee and Snoeyink, 1980).

One important aspect of this study concerned the effect of activated carbon adsorption on the trihalomethane formation potential (THMFP) of the remaining organic fractions. THMFP is defined as the quantity of THM produced per unit weight of TOC (e.g. $\mu \mathrm{g}$ THM mg TOC $^{-1}$ ). As previously reported by the authors and illustrated in Fig. 7, it was observed for the Aldrich humic acid solution that at least $70 \%$ of the unfractionated TOC had to be removed by activated carbon adsorption to achieve only about $20 \%$ reduction of THMFP (Jodellah and Weber, 1985). It appears from the information given in Table 4 and from the data presented in Fig. 7 that THMs are produced principally from the low to intermediate $\mathrm{MW}$ fractions of the Aldrich humic acid. These fractions comprise 90 and $76 \%$ of the organics remaining after reductions of TOC by carbon adsorption of 42 and $73 \%$, respectively. In contrast, $95 \%$ of the TOC of the untreated humic acid solution is in the low to intermediate MW range. It was thus necessary in this case to remove more than $70 \%$ of the overall TOC by adsorption to achieve a reduction of $<20 \%$ in organics in the low to intermediate MW fractions, which in turn effected a significant reduction in THMFP.

Adsorption breakthrough curves for humic substances in fixed-bed activated carbon adsorbers have been shown to manifest characteristically extended profiles (Weber et al., 1983; Weber and Jodellah, 1985). Figure 8 illustrates a breakthrough profile for the Contech fulvic acid in a bench-scale fixed-bed adsorber containing $10 \mathrm{~g}$ of F-400 GAC. The similarly extended profile exhibited here by the fulvic acid is likely attributable to the same phenomenon cited earlier for humic acid (Weber et al., 1983); namely, slow diffusion by certain molecular fractions of the organic mixture. To examine further the validity of this explanation, MW distributions were determined for both the influent and effluent of the fixed-bed

Table 3. TOC levels for Aldrich humic acid solutions after different types and degrees of treatment and concentration for molecular weight distribution analysis

\begin{tabular}{|c|c|c|c|c|}
\hline $\begin{array}{l}\text { Type and level } \\
\text { of treatment }\end{array}$ & $\begin{array}{l}\text { TOC after } \\
\text { treatment } \\
\left(\mathrm{mg} \mathrm{l}^{-1}\right)\end{array}$ & $\begin{array}{c}\text { TOC } \\
\text { removal } \\
(\%)\end{array}$ & $\begin{array}{l}\text { TOC after } 60: 1 \\
\text { concentration } \\
\left(\mathrm{mg} \mathrm{l}^{-1}\right)\end{array}$ & $\begin{array}{c}\text { TOC lost in } \\
\text { concentration } \\
(\%)\end{array}$ \\
\hline $\begin{array}{l}\text { Untreated } \\
\text { Treated with } 15 \mathrm{mg} \mathrm{l}^{-1} \text { alum } \\
\text { Treated with } 40 \mathrm{mg} \mathrm{l}^{-1} \text { alum } \\
\text { Treated with } 3 \mathrm{gl}^{-1} \mathrm{GAC} \\
\text { Treated with } 12 \mathrm{gl}^{-1} \mathrm{GAC} \\
\text { Treated with } 110 \mathrm{mg} \mathrm{l}^{-1} \mathrm{CaO} \\
\text { Treated with } 250 \mathrm{mg} \mathrm{I}^{-1} \mathrm{CaO}\end{array}$ & $\begin{array}{r}10.62 \\
5.02 \\
2.12 \\
6.13 \\
2.92 \\
8.44 \\
5.82\end{array}$ & $\begin{array}{l}-53 \\
80 \\
42 \\
73 \\
21 \\
45\end{array}$ & $\begin{array}{l}531.3 \\
241.2 \\
104.2 \\
286.4 \\
165.9 \\
244.6 \\
170.5\end{array}$ & $\begin{array}{r}17 \\
20 \\
18 \\
22 \\
5 \\
52 \\
51\end{array}$ \\
\hline
\end{tabular}

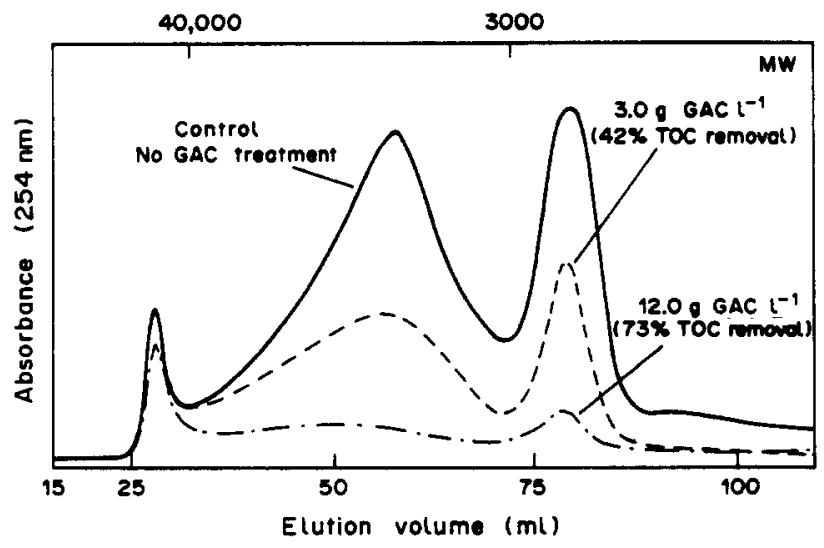

Fig. 6. Gel permeation chromatograms for Aldrich humic acid before and after GAC treatment. 
Table 4. Molecular weight distributions for Aldrich humic acid before and after GAC adsorption

\begin{tabular}{|c|c|c|c|c|c|}
\hline \multirow{2}{*}{$\begin{array}{l}\text { Molecular } \\
\text { weight } \\
\text { range }\end{array}$} & \multirow{2}{*}{$\begin{array}{c}\text { Composition of } \\
\text { untreated solution } \\
(\%)\end{array}$} & \multicolumn{4}{|c|}{$\begin{array}{l}\text { Reductions and composition after GAC treatment } \\
42 \% \text { TOC removal } \\
\begin{array}{ll}73 \% \text { TOC removal }\end{array}\end{array}$} \\
\hline & & $\%$ Removal & $\%$ Composition & $\%$ Removal & $\%$ Composition \\
\hline $\begin{array}{c}>40,000 \\
3000-40,000 \\
<3000\end{array}$ & $\begin{array}{r}5 \\
57 \\
38\end{array}$ & $\begin{array}{r}0 \\
45 \\
64\end{array}$ & $\begin{array}{l}10 \\
62 \\
28\end{array}$ & $\begin{array}{l}25 \\
85 \\
89\end{array}$ & $\begin{array}{l}24 \\
56 \\
20\end{array}$ \\
\hline
\end{tabular}

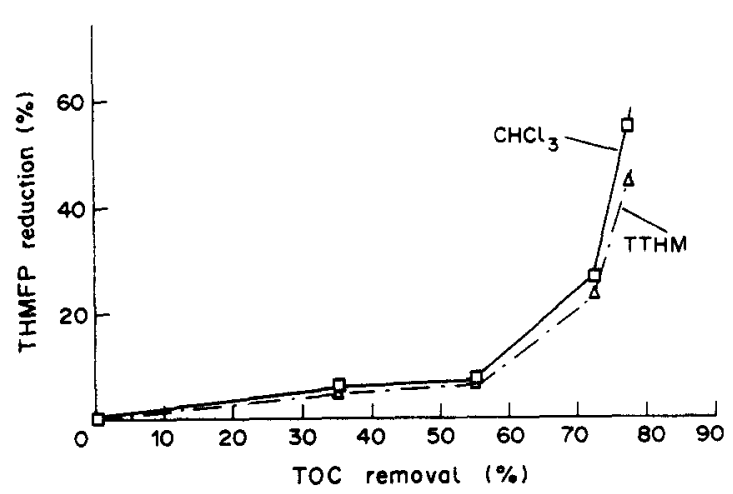

Fig. 7. Effects of GAC treatment on THMFP of humic acid (after Jodellah and Weber, 1985).

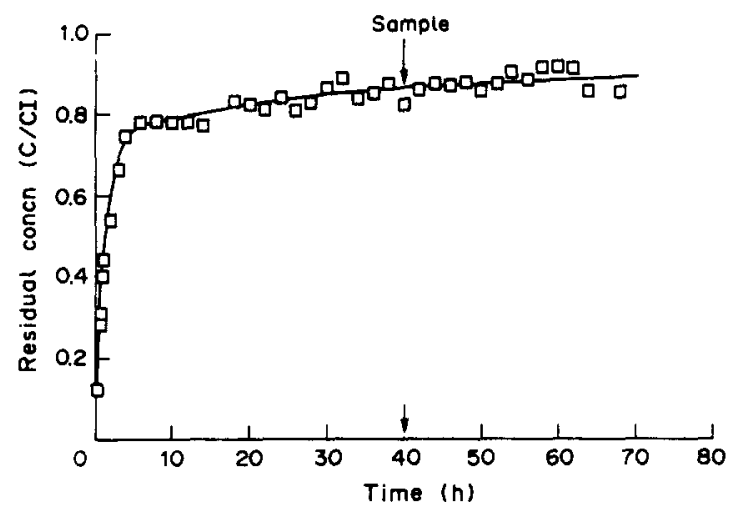

Fig. 8. Adsorption of Contech fulvic acid in a fixed-bed adsorber $(10 \mathrm{~g} \mathrm{40/50} \mathrm{U.S.} \mathrm{sieve} \mathrm{size} \mathrm{F-400} \mathrm{GAC;} \mathrm{flow}$ rate $=3.4 \mathrm{gal} . \mathrm{min}^{-1} \mathrm{ft}^{-2}$ ). adsorber after $40 \mathrm{~h}$ of operation. The results are presented in Fig. 9. Qualitatively, the MWDs indicate that adsorber breakthrough with respect to organics in the intermediate $\mathrm{MW}$ range occurred somewhat more rapidly than it did for those in the high and low MW ranges. It appears that molecules in the latter two fractions continue to be removed in a process involving relatively slow diffusion into carbon pores of comparable sizes after molecules in the intermediate MW range have essentially exhausted the capacity of the carbon to further effect their removal. This qualitative observation, although hardly conclusive at this juncture, further suggests the importance of the pore size distribution within the activated carbon particles and its relationship to the molecular size distribution of organics in the humic mixture.

Alum treatment. The MWDs for untreated Aldrich humic acid solution and for organics remaining after treatment with alum are illustrated in Fig. 10. Two levels of TOC removal by alum were examined; a $53 \%$ TOC removal ( $15 \mathrm{mg} \mathrm{l}^{-1}$ of alum) and an $80 \%$ TOC removal ( $40 \mathrm{mg} \mathrm{l}^{-1}$ of alum). The results are summarized in Table 5. At 53\% TOC removal approx. 85 and $69 \%$ of the organics were removed from the intermediate and low MW fractions, respectively. In contrast, the organics in the high $\mathrm{MW}$ fraction actually increased by $58 \%$. This might have resulted from the aggregation of molecules of $\mathrm{MW}<40,000$ by alum coagulation, coupled with the fact that the alum dosage at this treatment level was insufficient to effect complete destabilization of these aggregates and induce their removal. On the other hand, the alum dosage at $80 \%$ TOC removal appeared to be

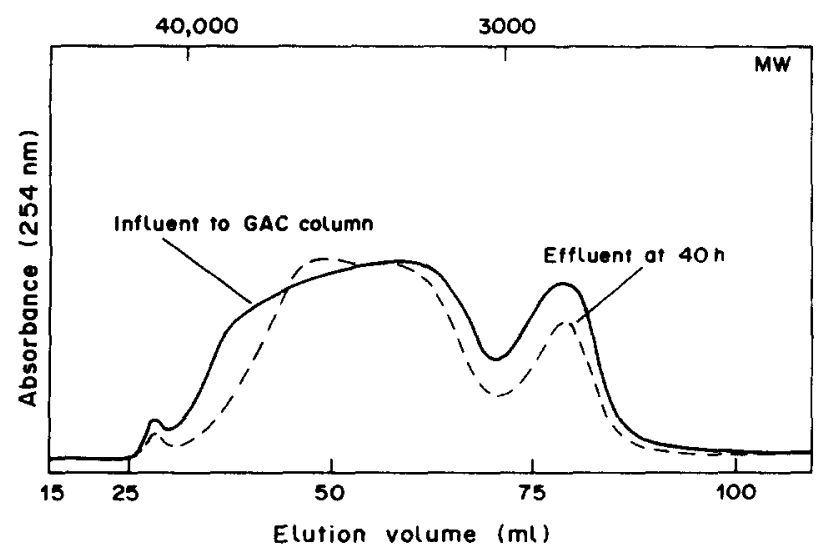

Fig. 9. Gel permeation chromatograms for Contech fulvic acid before and after GAC treatment. 


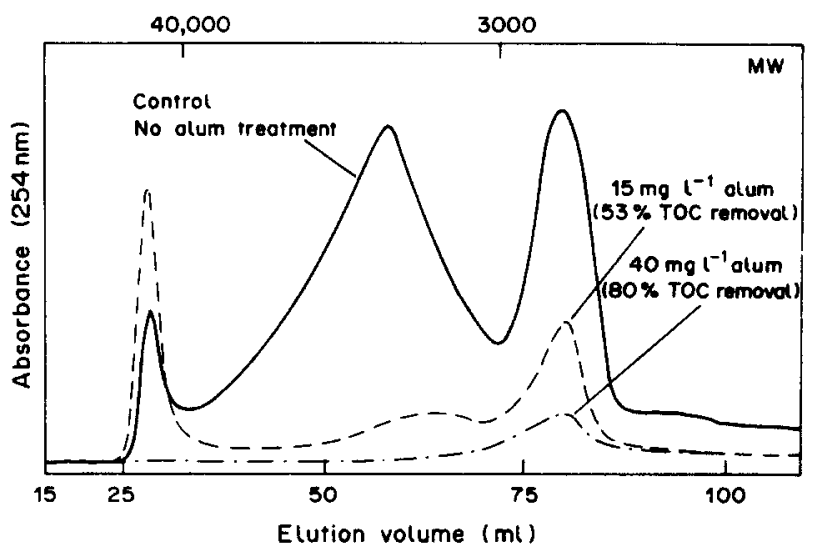

Fig. 10. Gel permeation chromatograms for Aldrich humic acid before and after alum coagulation.

Table 5. Molecular weight distributions for Aldrich humic acid before and after treatment with alum

\begin{tabular}{|c|c|c|c|c|c|}
\hline \multirow{2}{*}{$\begin{array}{c}\text { Molecular } \\
\text { weight } \\
\text { range }\end{array}$} & \multirow{2}{*}{$\begin{array}{l}\text { Composition of } \\
\text { untreated } \\
\text { solution } \\
(\%)\end{array}$} & \multicolumn{4}{|c|}{$\begin{array}{l}\text { Reductions and composition after Alum treatment } \\
52 \% \text { TOC removal } \\
80 \% \text { TOC removal }\end{array}$} \\
\hline & & $\%$ Removal & $\%$ Composition & $\%$ Removal & $\%$ Composition \\
\hline $\begin{array}{c}>40,000 \\
3000-40,000 \\
<3000\end{array}$ & $\begin{array}{r}5 \\
57 \\
38\end{array}$ & $\begin{array}{r}-58 \\
84 \\
69\end{array}$ & $\begin{array}{l}27 \\
32 \\
41\end{array}$ & $\begin{array}{r}100 \\
98 \\
84\end{array}$ & $\begin{array}{r}0 \\
18 \\
82\end{array}$ \\
\hline
\end{tabular}

capable of increasing aggregation sufficiently to cause destabilization and essentially complete removal of organics in this high $\mathrm{MW}$ range. At this higher treatment level 98 and $84 \%$ of the organics in the intermediate and low $\mathrm{MW}$ fractions, respectively, were removed.

Figure 11 is a plot of data which indicates that treatment of an Aldrich humic acid solution by alum sufficient to effect a $50 \%$ TOC reduction resulted in a residual TOC having a lower adsorption capacity than that of the untreated solution (Weber and Jodellah, 1985). The MWDs summarized in Table 5 help to provide a possible explanation for these findings. As indicated in this table $27 \%$ of the organics remaining after a $53 \%$ TOC reduction by alum coagulation are of very high $\mathrm{MW}$, compared to only $5 \%$ in the untreated solution. The adsorption data given in Fig. 6 and Table 4 indicate that organics in the highest MW range are the least adsorbable. Because this fraction constitutes a higher percentage of the residual organics in the solution treated to $53 \%$ TOC reduction by alum than it does in the untreated solution, the treated solution might be expected to manifest a lower overall propensity for adsorption.

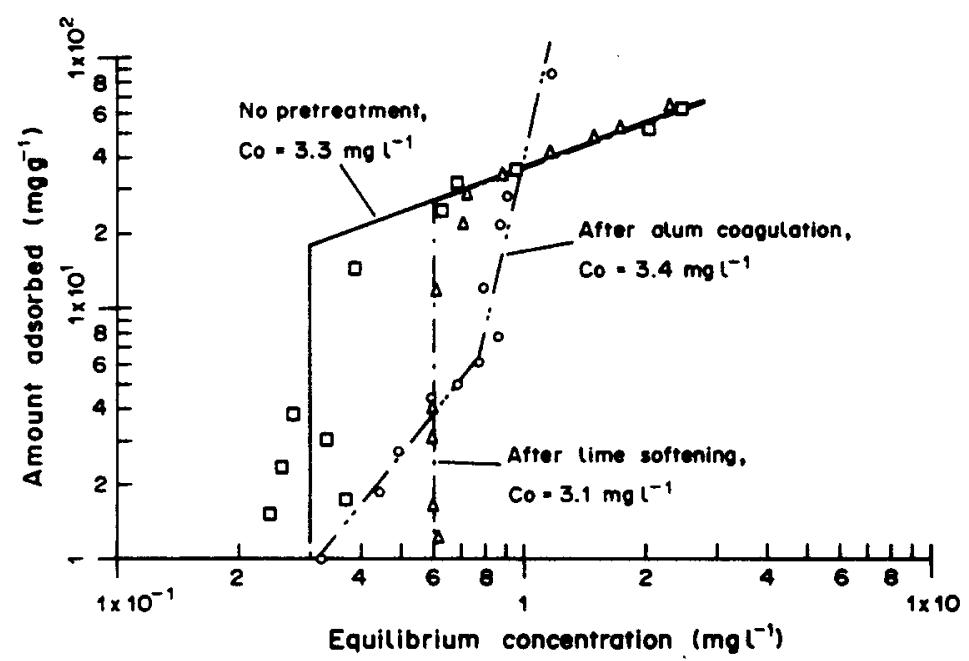

Fig. 11. TOC adsorption isotherms for Aldrich humic acid before and after chemical pretreatment (after Weber and Jodellah, 1985). 


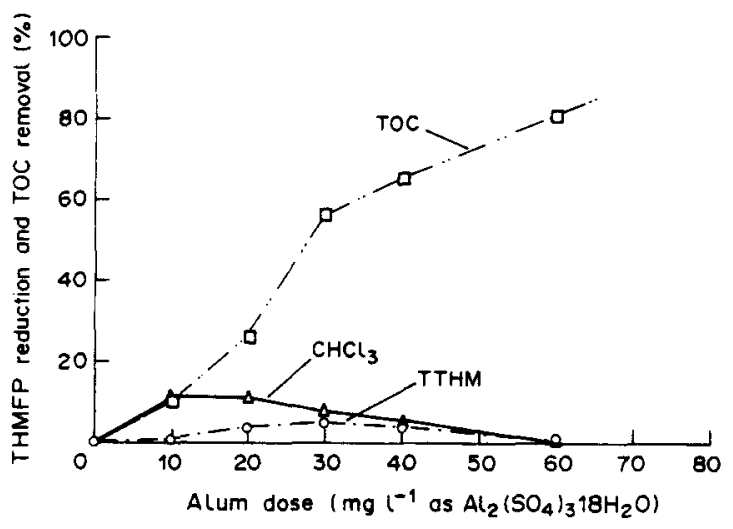

Fig. 12. Effects of alum coagulation of Aldrich humic acid on TOC removal and THMFP (after Jodellah and Weber, 1985).

The results in Table 5 further indicate that the organics remaining in a humic acid solution after a higher level of TOC removal by alum treatment $(80 \%$ TOC reduction) will have a greater tendency for adsorption than will those in the untreated precursor solution, due to the essentially complete removal of organics having $\mathrm{MWs}>\mathbf{4 0 , 0 0 0}$. It is important to note that these findings are specific to the Aldrich humic acid tested, and they may or may not apply to other commercial humic or fulvic acid preparations or to organics comprising TOC in natural water systems. Indeed, the results of earlier studies on both the Contech fulvic acid preparation and the Huron River water investigated in this work demonstrated different adsorption behavior on the part of these organic mixtures than that observed for the Aldrich humic acid mixture, both before and after treatment with alum (Weber and Jodellah, 1985). As indicated in Table 1 , it is likely also that their MWDs differ significantly after alum coagulation. Such differences suggest caution with respect to any generalization of the results reported here to mixtures other than those specifically tested.

MWDs measured for the Aldrich humic acid after alum coagulation provide some insight to the trihalomethane formation behavior of this compound as reported in an earlier study (Jodellah and Weber, 1985). As shown in Fig. 12 there is an intermediate range of TOC reduction (10-70\%) by alum coagulation in which a reduction in THMFP also obtained. If the TOC reduction is increased much beyond this range, no reduction in THMFP is accomplished. Table 5 indicates that at $53 \%$ TOC removal by alum treatment about $73 \%$ of the organics in the remaining solution are comprised by the intermediate to low MW fractions, the fractions most responsible for THM formation, compared to $95 \%$ in the untreated solution. On the other hand, at $80 \%$ TOC reduction the intermediate to low MW fractions comprise almost all of the remaining organics, and the THMFP of this highly treated solution is correspondingly as high as, or greater than, that of the untreated solution.

Lime treatment. The MWDs for untreated Aldrich humic acid solution and for organics remaining after lime softening are illustrated in Fig. 13 and the results summarized in Table 6. As in the experiments with adsorption and alum coagulation, two levels of TOC removal were examined; a $21 \%$ TOC removal $\left(110 \mathrm{mgl}^{-1}\right.$ of $\mathrm{CaO}$ ) and a $45 \%$ TOC removal

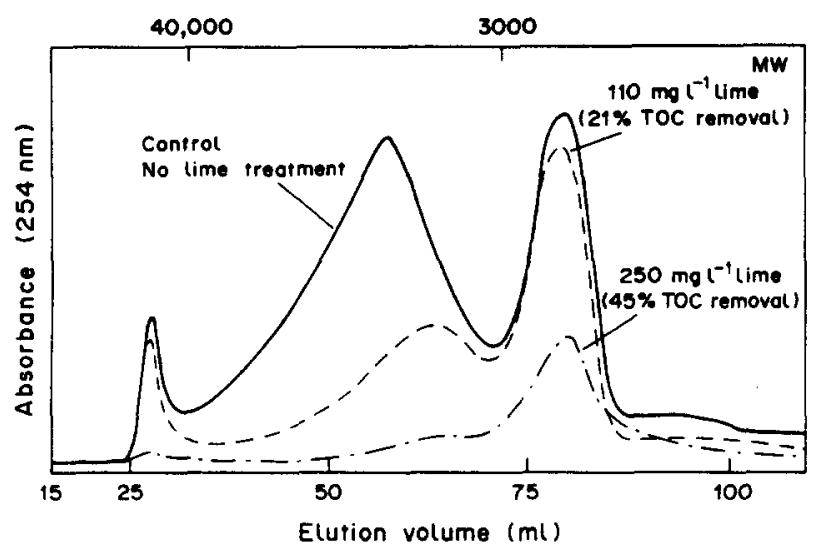

Fig. 13. Gel permeation chromatograms for Aldrich humic acid before and after lime softening.

Table 6. Molecular weight distributions for Aldrich humic acid before and after treatment with lime

\begin{tabular}{|c|c|c|c|c|c|}
\hline \multirow{2}{*}{$\begin{array}{l}\text { Molecular } \\
\text { weight } \\
\text { range }\end{array}$} & \multirow{2}{*}{$\begin{array}{l}\text { Composition of } \\
\text { untreated } \\
\text { solution } \\
(\%)\end{array}$} & \multicolumn{4}{|c|}{$\begin{array}{l}\text { Reductions and composition after lime treatment } \\
21 \% \text { TOC removal } \\
45 \% \text { TOC removal }\end{array}$} \\
\hline & & $\%$ Removal & $\%$ Composition & $\%$ Removal & $\%$ Composition \\
\hline$>40,000$ & 5 & 22 & 9 & 90 & 2 \\
\hline $3000-40,000$ & 57 & 59 & 42 & 94 & 23 \\
\hline$<3000$ & 38 & 25 & 48 & 67 & 75 \\
\hline
\end{tabular}




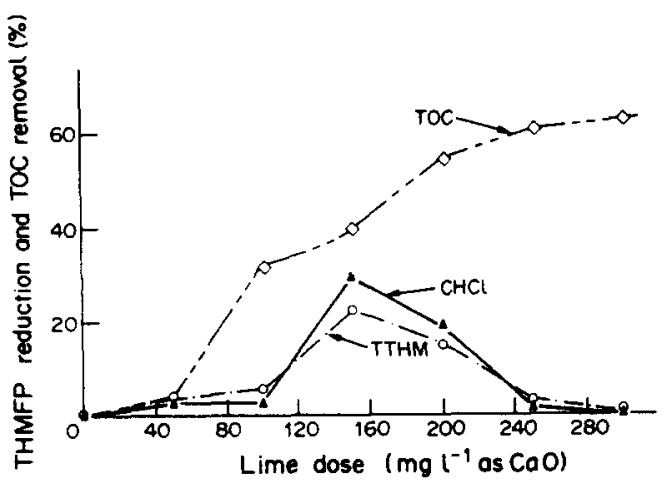

Fig. 14. Effects of lime softening of Aldrich humic acid on TOC removal and THMFP (after Jodellah and Weber, 1985).

$\left(250 \mathrm{mg}^{-1}\right.$ of $\mathrm{CaO}$ ). The data in Table 3 indicate that excessive amounts of TOC were lost during the concentration of the lime-treated solutions. This is also evidenced by comparison of the areas under the chromatograms of Fig. 13. Interpretation of the lime treatment results thus require consideration of the possibility that the effects of lime softening alone may have been overshadowed by precipitation of TOC during the concentration step. If TOC reduction in the course of sample concentration is added to that which occurred directly as a result of lime addition, the two treatment levels according to the chromatograms are actually 44 and $83 \%$, rather than 21 and $45 \%$, respectively, obtained by softening alone. The same reasoning that was applied in the case of alum coagulation can be used to explain observations of the activated carbon adsorption and THMFP behavior of Aldrich humic acid reported earlier and reproduced in Figs 11 and 14, respectively (Weber and Jodellah, 1985; Jodellah and Weber, 1985). At about $21 \%$ TOC removal by lime ( $44 \%$ removal considering concentration loss), the intermediate to low MW fractions comprise $91 \%$ of the organics remaining after treatment, compared to $95 \%$ in the untreated solution. This small level of reduction (4\%) was not enough to affect the adsorption capacity of the treated solution measurably (see Fig. 11). On the other hand, a $4 \%$ reduction in the intermediate to low MW fractions, which are more amenable to THM production, could result in a reduction of the THMFP of the remaining solution. At $45 \%$ TOC removal by lime $(83 \%$ removal considering concentration loss), the intermediate to low MW fractions comprise about $98 \%$ of the remaining organics, and the remaining solution can be expected to have a THMFP equal to, or greater than, that of the untreated solution.

\section{CONCLUSIONS}

It is clear that humic and fulvic substances are mixtures of organic compounds of different molecular weight, that the distribution of molecular weights varies among different commercial preparations of humic and fulvic acids and different natural waters, that different distributions yield different behaviors with respect to water treatment operations, and that such treatments alter the distributions and phenomenological behavior in subsequent process operations. While both the qualitative and quantitative impacts of such effects are specific to particular humic mixtures and particular treatment operations, several general observations can be made.

Gel permeation chromatography is a useful techique for determination of the molecular weight distributions of humic substances and such determinations provide useful insights to the observed and anticipated behavior of these substances in water treatment operations.

Different molecular weight fractions of humic substances adsorb to different extents on activated carbon, the higher MW fractions $(>40,000)$ being least adsorbable. This is likely attributable to the inability of the very large molecular fractions to penetrate the micropore structure of activated carbon, and suggests an interrelationship between MWD, carbon pore size distribution, and the effectiveness of adsorption for removal of humic substances.

Alum coagulation and lime softening remove organic fractions in different $M W$ ranges to different extents, resulting in changes in the MWDs of residual organics from those of untreated precursor solutions.

The extent of TOC removal from each MW fraction depends on the level of treatment practiced. Treatment with activated carbon, alum coagulation, or lime softening to high levels of TOC reduction results in different residual molecular weight proportions than does treatment by similar means to lesser levels of TOC reduction.

The low to intermediate MW $(<40,000)$ fractions of humic acid mixtures are predominantly responsible for THM production during chlorination. This conclusion is based on the observation of a direct correlation between the percentage of these fractions in a water and the trihalomethane formation potential of that water.

Acknowledgement - The work described in this paper was supported in part by Research Grant No. 80735901 from the Exploratory Research Programs, U.S. EPA. The contents of the article do not necessarily reflect the policies of the U.S. EPA, nor does the mention of trade names and commercial products constitute endorsement.

\section{REFERENCES}

Cazes J. (1966a) Gel permeation chromatography-part one. J. chem. Educ. 43, A567-A582.

Cazes J. (1966b) Gel permeation chromatography-part two. J. chem. Educ. 43, A642-A652.

Cazes J. (1970a) Current trends in gel permeation chromatography-part one: theory and equipment. J. chem. Educ. 47, A461-A471.

Cazes J. (1970b) Current trends in gel permeation chromatography-part two: methodology. J. chem. Educ. 47, A505-A514. 
Gjessing E. and Lee G. F. (1967) Fractionation of organic matter in natural waters on Sephadex columns. Envir. Sci. Technol. 1, 633-638.

Jodellah A. M. and Weber Jr W. J. (1985) Controlling THM formation potential by chemical treatment and adsorption. J. Am. Wat. Wks Ass. 77, 95-100.

Lee M. C. (1980) Humic substances removal by activated carbon. Ph.D. dissertation, University of Illinois.

Lee M. C. and Snoeyink V. L. (1980) Effect of GAC pore size distribution and alum treatment on the adsorption of humic substances. 1980 Annual Conference Proceedings, pp. 319-328. American Water Works Association, Denver, Colo.

McCreary J. J. and Snoeyink V. L. (1980) Characterization and activated carbon adsorption of several humic substances. Water Res. 14, 151-160.
Rest C., Hoehn R. C., Knocke W. R. and Novak J. T. (1983) The removal of specific molecular weight fractions of trihalomethane precursors by alum coagulation. 1983 Annual Conference Proceedings, pp. 447-440. American Water Works Association, Denver, Colo.

Schnoor J. L., Nitzschke J. L., Lucas R. D. and Veenstra J. N. (1979) Trihalomethane yields as a function of precursor molecular weight. Envir. Sci. Technol. 13, 1135-1138.

Weber Jr W. J. and Jodellah A. M. (1985) Removing humic substances by chemical treatment and adsorption. J. Am. Wat. Wks Ass. 77, 132-137.

Weber Jr W. J., Voice T. C. and Jodellah A. (1983) Adsorption of humic substances: the effects of heterogeneity and system characteristics. J. Am. Wat Wks Ass. 75, 612-619. 